Alena Vališová

České vysoké učení technické, Masarykiov ústav vyšších studií

\title{
SEARCHING OF KEY PROBLEMS OF THE CONTEMPORARY UPBRINGING AND EDUCATION IN THE CZECH REPUBLIC
}

\begin{abstract}
AвSTRACt. Vališová Alena, Searching of Key Problems of the Contemporary Upbringing and Education in the Czech Republic [Analiza podstawowych problemów współczesnego kształcenia i wychowania w Republice Czeskiej]. Studia Edukacyjne nr 52, 2019, Poznań 2019, pp. 291-302 Adam Mickiewicz University Press. ISSN 1233-6688. DOI: 10.14746/se.2019.52.19

The study tries to analyze briefly the current questions of the contemporary school system in the Czech Republic. The ongoing transformation of our school system implied specification of the basic key problems, in the socio-economical, philosophical, sociological, psychological, and pedagogical context. The respective problems are intentionally presented only with their brief characteristics, without taking a stand to them. Such a stand should be taken only after a qualified expert consideration of individual spheres of the problems mentioned.
\end{abstract}

Key words: transformation of the school system, school, school system, upbringing, education, school attendance, family, school institutions, current problems of the Czech school system

\section{Introduction}

One of the serious shortcomings, both of the theory of the general didactics and the school practice at present, is the insufficient specification of the basic spheres of problems which can be met in our country both on the theoretical level and in the research projects but also in the real school practice. The presented article tries to search and characterize briefly the key problems. Changes, innovations, and transformations, that more or less reflect partial aspects of the school system, are underway for a couple of decades, but studies of a more complex character are still missing. Inasmuch as the already presented proposals do not specify the spheres of these problems in its entirety and are in fact mostly focused on solution of the partial questions, there is a danger 
that the discussion to the proposals of the constructive transformation will miss the expression to the basis of the fundamental changes, to the philosophy of education and will be limited to a number of entirely concrete problem that cannot be solved independently without taking into account the solution of the basic conceptual questions. This study therefore tries to highlight at least such spheres of problems that in the socio-economical, philosophical, sociological, psychological, and pedagogical context must constitute a part of the upcoming conception of transformation of our school system.

\section{Changes in the society and transformation of the family in the context of upbringing and education}

Social changes have in substance a dual character. On the one hand there are worldwide changes reflected in some or other measure also in the life of the Czech society and on the other hand it concerns some specifics typical for the situation in the country that over a long period copes with problems associated with the transition to a democratic society under the typical Czech conditions.

As far as the worldwide, global trends, are concerned it is possible to mention at least some of its features:

A typical feature of the "western" civilization in particular is the trend towards formation of a performance-related society. This fact necessarily leads to the change of value structures when preference is given to performance before a number of another for example spiritual values. As a consequence of this fact the society is structured into successful and unsuccessful individuals, and at the same time the rate of successfulness is usually an external indicator (status, material values and so on). Quick division of countries to the rich and poor ones takes place also worldwide what of course often causes unrest in the poorest countries sometimes reflected in the hatred, xenophobia, illegal migration and in the last resort also in terrorism. ${ }^{1}$

An important feature of the last decades is the information explosion. It consists on the one hand in huge growth of information in individual disciplines what in the pedagogical sphere creates the necessity of outlining of new education programmes including specification of the basic curriculum sphere and on the other hand it forms a vast space for communication of these information. Internet, news media, mobile phones and likewise markedly change the manners of communication. The media furthermore become very important means of influencing in particular the stances and views of exter-

${ }^{1}$ J. Pelikán, Pomáhat být: otevřené otázky teorie provázející výchovy [Help to be: open questions of the theory accompanying education], Praha 2002. 
nally managed personalities ${ }^{2}$ what applies today to majority of the peoples. Ordinary communication is sometimes replaced by the technically mediated communication.

An important problem of the contemporary society is maintenance of the sustainable development not endangering the living conditions on this planet. Finding of the balance between the economic development and at the same time keeping of the natural resources represents a difficult problem for solution.

The man becomes a member of many social groups and societies that make demands on him. The ideas and traditions of these groups can be often very different. This fact leads to disintegration of the personality, to loss of the identity but also to loss of the meaning of life and active living position. The conformity often required in this case however makes also difficulties due to the diversity of requirements and expectations of the frequently different groups.

To these key global problems can also be added some of the so called mortal sins of the mankind ${ }^{3}$ to which ranks for example hurriedness of the times, overpopulation of the housing estates leading to disinterest about others, to unconcern, emotional dullness, to the moral and value relativism, to loss of the sense of responsibility, dismiss of the traditions, and growing pliancy towards the doctrines.

To some of the Czech specifics can be included:

Transition to a democratic society that leads to searching of the social life standards This results in searching of the relation between freedom and responsibility for oneself and also for the others, between the rights and duties, comprehension of ethics, values, internal discipline, authority and likewise.

In such a situation, when it comes to a great differentiation among the people and to opening of scissors between the rich and poor ones, arises a new necessity of searching ways for help to the others, and altruistic behaviour towards those in need. Nowadays it is no more possible to count only upon the state. Now arises a now situation for mutual help and solidarity with the others.

Opening of the possibility to acquire a higher living standard leads on the one hand in many cases to postponing of the term for establishing a family and the birth of children, and on the other hand to the fact that parents often do not have enough time for the family life and the basis of family upbringing has another character than it was before.

These facts are increasingly connected with the focus on professional growth and career (the phenomenon of two-career marriages or partnership).

\footnotetext{
${ }^{2}$ In more detail see: D. Riesman, Osamělý dav [Lonely crowd], Praha 1968.

${ }^{3}$ See: K. Lorenz, 8 smrtelných hř́chů [Eight mortal sins], Praha 1990.
} 
Significant reduction of the birth rate on the one hand results in closing of schools, and change of the cultural background in smaller places and on the other hand in a growing number of only children that often leads to another conception of upbringing in such families.

Furthermore constantly continues the diminution of the contemporary family's stability (high divorce rate in relation to the marriages rate, and extra-marital relations).

Quite common is the growing variability of the family types, comprising not only the complete family itself but also the one-parent family, incomplete and surrogate family.

The latest phenomenon in our country today is also prolongation of the lifetime and decreased rate of mortality which results in the fact that young families must often take care of their own children and of their ageing parents as well.

The opening up to the world in connection with the accession to the EU results in necessity to count with a distinctly higher migration and arrival of people from another sometimes diametrically different cultures. The problem of multiculturalism leads to new views on education towards understanding and toleration of people from another countries and therefore also cultures, traditions and standards. The problem of "being different" traditionally constitutes already an emotional issue in the Czech countries.

\section{Attempt to set down key problems of upbringing and education at the contemporary school}

The respective changes in the sphere of development, changes in the society and also transformation of the family are reflected in the theory of pedagogy and its partial disciplines, and in the environment of the concrete Czech school as well. The general didactics as a "queen" of the education sciences is distinctly influenced by the above mentioned processes positively but sometimes also negatively. The selected key problems of the contemporary school system will be highlighted in the subsequent enumeration and characterization. To some of the mentioned problems will be paid more attention and some of it will be characterized only very briefly. The objective of this approach is to inspire to a more profound considerations of the respective questions and deliberation of the individual contexts in the enumeration of partial problems and its completeness.

Primarily are mentioned the following ones:

\section{Education and its standing in our society}

An important question concerns the relation of the society to education and correction of the state that existed in the past regime (for example underesti- 
mated education, inadequate appraisal of specialists). It is important to understand education and its value as a priority especially in a small state that can compete to other countries right in this sphere.

How to understand rightly the relation of investment into education for the future and its return? Investment into the school system according to the state of our society's economy - shall we wait until our economy will be strong enough to find the means also for the school system or will we rather proceed by a purposeful reallocation of the budget amounts and invest into education economically with forethought what will consequently significantly influence the economic growth?

A new conception of the quality of education and its reflection into the preparedness of graduates is at present very important. This means that the practice and market today call for specialists and not only for mere school graduates. The new quality of education must be unequivocally reflected into the real preparedness of graduates to perform a concrete profession.

\section{New qualities of the education and its definition}

In relation to this definition arises a whole range of problems including the conceptual specification - what can be understood under the concepts education, general education, technical education, professional preparation, polytechnic education and likewise. Under this specification fall also questions as are - relation of science, technology and school education, including the information explosion and also questions connected with information education (skills that concern the selection of information, its processing and evaluation; use of technical means and digital information sources for acquirement of information but also use of classical printed text materials and likewise). For education is very important to keep up with the rapid development of the science and technology and this applies for the prognostic as well.

From this results also the requirement to carry out the respective methodology of ascertainment of the social demands on education and its transformation into the contents of education (the so called didactical transformation). Will from the new conception of education result also emphasis on its individual aspects (for example progress in thinking, lead to creativity or will be still emphasized the encyclopedic education? Will it mean reversion to the problem between the classical and material education? Will it come about the solution of knowledge synthesis and leading of pupils towards creation of the world's comprehensive picture or will be preserved the subject fragmentation resulting in isolation of the knowledge?).

Another exigent problem to be solved is the specification of the basic contents of education under the conditions of information explosion however not only 
on the cognitive level (i.e. what kind of knowledge to acquire) but also what sort of personal qualities and on what level, should be created and so on.

\section{Education and its democratization}

Very briefly will be mentioned the necessity to clarify the principle of the democratic character of education as it is the availability of education for everybody, regardless of the social differences. To this furthermore pertains the creation of conditions for children in the context of special needs for pupils with certain handicaps (physical, mental and also social), but also for the talented individuals.

In relation to the above mentioned issues comes into forefront the necessity to deal once again with the problem of an unified, internally differentiated school - its analysis, how to understand it for the present, in what consists its oneness and in what consists the space for differentiation.

\section{Problem of the unification or differentiation of education}

Invariably up-to-date is the clarification, whether to continue in striving about the only one education system or to release it for the alternative school system, and not only as to the institutional but also as to the contents and methodical nature thus it is not only the case of the different variants of schools but also whether it is possible to allow the contents and methodical variability for the state school system as well. The differentiation as such can be understood on the level of three kinds a) in the context of the school perceived as an institution (alternative schools, relation of RVP and ŠVP); b) from the contents point of view (not only the contents of subjects' curriculum but also the possibility of using alternative textbooks and study texts); c) with respect to the interests of the pupil, his performance and real abilities.

A further sub-problem is the question, whether the state schools will remain a basic type of the Czech schools and other schools will constitute an alternative, or whether the priority of the state schools will not be emphasized. From the solution of these questions then results also a number of consequences (it concerns for example the profiles of graduates, whether there will be a unified contents, unified curriculum, textbooks or whether it will be a case of a limited or entirely free variability with the possibility to create preconditions for the comparability of education by way of standards and to leave to schools a full degree of freedom).

In the broader context it concerns also the external and internal differentiation of pupils according to their abilities, performance and interest. The relatively frequent used differentiation based only on doing well at school is unreasonable and is more detrimental than it helps to solve the questions of a differentiated approach to the pupils. The main role in the differentiation must prima- 
rily play the pupil's interest, his performance and real abilities. Consequently it cannot be a case of a general differentiation and ranking of pupils into the clever ones and their antipole but such differentiation should be in accord with the dispositions for various spheres of knowledge and activity.

However, such differentiation cannot be ensured without a well - equipped network of pedagogical and psychological consultancy.

\section{Problem of the mutual permeability of individual schools}

Permeability of individual schools is another serious problem. Markedly higher differentiation of the school types that can be envisaged must be resolved so that it enables the pupil to change over from one school to another both at the horizontal and vertical level especially on the primary and secondary level of education.

The permeability is also closely related to solution of the question concerning the so called intermediary stages between the secondary and high school (problem of the follow-up studies, eventually its change into institutions of the American college type or in studies concluded by a bachelor's degree at the high school).

The change over to another school also relates to the problem, whether and on what basis will be assessed the level of preparation at a certain school, including the private one. Is there still taken into account that in case of a change over to another type of school, such change over should be enabled to the pupil from a school that possesses on a verified level (based for example on achieving standards), the approval of the accreditation committee enabling its pupils or graduates to change over to the state school system without additional examinations? Wouldn't there perhaps be established such committees also for another types of alternative schools or for the state schools as well? The mentioned questions should be understood only as a partial inspiration for the more profound considerations.

\section{Problem of the pupil's position at school}

The modern conception of education also considerably changes the point of view on the pupil's position in the education process. The pupil is increasingly understood as a subject and not as an object of the education itself and the general development. This fact requires considerable changes in the conception of the whole pedagogical process as it primarily anticipates activity of the markedly motivated pupil and transformation of the school from a coercive facility to a "workshop of humanity and adventure of the spirit."

Such a change of course brings a number of questions. Have in the society already been created conditions so that acquirement of real knowledge by way of education could be a sufficiently motivation factor for the pupils and 
their parents as well? Does not still survive the state, well-established in the preceding regime, when the real education was replaced by mere documents about education, thanks to the protection, corruption and political machinations in the society? Does the education already have sufficient prestige in the social consciousness so that it could motivate the pupils? Is the present school system sufficiently prepared for this fundamental change of the conception without which all the reforms must fail? Are we able to reduce the considerable number of pupils at the class so that it could come about the individualization of the pupil's work? Do we have sufficient technical equipment at schools for the independent active pupil's participation on the teaching process? Are the teachers psychically, professionally and also methodically prepared for this considerable change in the conception of work at school? Answers and concrete variants of solution to this and suchlike questions are today still searched.

\section{Problem of the teacher's position at school}

Any kind of transformation without the teachers is unthinkable. The transformation therefore anticipates to win the teachers interest in such changes, their motivation, initiation of the discussion, creation of a platform for meeting of creative teachers - reformers. Fundamental in this respect must be creation of a space for the teachers' creativity, bestowal of confidence and at the same time expose the teachers to the pressure of the public. Emphasis is today placed also on more intensive and constructive cooperation of the school and the family.

The issues mentioned above beg a question of the social appreciation of the pedagogical work (the untenable situation, when the judges, who occupy themselves with delinquents, are paid three times up to four times more than those who with their good work help to prevent delinquency).

The quality improvement of the teaching staff is only hardly possible without a sufficient material support. This issue relates to the problem of future teachers' choice (the entrance exams of future teachers cannot be based only on the knowledge tests but also on ascertainment of their motivation and personal preconditions (by the most objective forms), on the conception of preparation (who and on what level of preparation, at which type of the school or faculty, clarification of the contents of the preparation in comparison with the world by a Teacher's charter and likewise) but also the control of teacher"s work - evaluation of their work in accord with the real results of pedagogical work and not as to date - wage levelling or awards for non-pedagogical "merits", or for quantitative and not qualitative evaluation of the teacher's work.

Systematic work with teachers can also be considered as a problem. Instead of detailed manuals of a methodical character, the teachers should be led to 
understanding of the philosophy of upbringing and education, on the base of which everybody can realize the pedagogical work in a creative manner, in accord with the corresponding conditions of the concrete subject, school, class and also personal temperament and experiences.

The respective retraining for this purpose should be therefore completely of a different type as it is to date. Pedagogical and psychological preparation, corresponding to the above mentioned conception, training in communication, social training, and creative exercise should take place apart from the professional preparation, what altogether could provide the teacher with preconditions for creative approaches and social capability. Frontal releasing of the possibilities for creative work without the preliminary preparation of teachers could result in disorientation of teachers who were until recently accustomed to the fact that they are controlled in detail and for the most part they are not able to use the freedom for the pedagogical work.

The same what is valid for the teachers concerns also the new way of work with directors of the schools, their deputies, the new preparation and retraining of education consultants, new specification of the pedagogical and psychological advisory centres' mission that should get more closer to the schools and to help the teachers come to know the pupil's individualities, and so on.

\section{Education and the problem of its orientation}

This concrete problem, in the context of upbringing and education, will be treated rather reflective, as it relates to a whole range of partial questions that have not been solved for the present. Further will be mentioned some of these questions. A part of these questions is focused on the consideration who should be actually educated at school:

What proportion should be between the education towards national feeling and education towards Europeanism or cosmopolitism?

Will we educate successful, independent, authentic citizens or servants of impersonal social institutions?

What proportion should be between the education of individualities and socialization (adaptation and maladaptation)?

Will we educate revolutionists or citizens ready to do reforms in the society that will not be characterized by revolutionary upheavals?

What share in forming of the personality should have the professional preparation and what share should be delimitated to the humanization disciplines, cultivating the personality? This consideration results in further questions: What limits should be determined in case of the general education for the entire population, and when to begin with specialization for all the pupils (and also for example for those very talented ones)? Should the professional preparation be extensively oriented in view of the better assertion of graduates or should in 
some disciplines come about a higher specialization? An important problem of a key relevance is the professional preparation for the blue-collar professions and craftsmen and its conception under the conditions of privatization.

The second group of partial questions concerning the sphere of education and its orientation relates to the proportions of individual components of education:

What should be the proportion of the classical and modern education (the share of classical languages, the share and extent of the history itself, history of literature, music, fine arts, science, and how much attention should be paid to the modern languages, how to incorporate into the general education the modern disciplines as is informatics, ecology but also psychology and sociology and perhaps in view of the upbringing in families also pedagogy).

Will we stay at the classical sorting of subjects or will we consider a new conception of the disciplines, as of the integrated, interdisciplinary approached disciplines, or will we alternatively combine both conceptions?

\section{Results of the pedagogical process and problem of the criteria for its evaluation}

Should the newly designed pedagogical process be sufficiently effective then it is necessary to create sufficiently objective criteria for its evaluation. The research projects show that doing well at school does not constitute such a criterion. However, are we able to define sufficiently precise criteria for judgment of the pupil's preparedness but also of the teacher's work and of the school? The overestimation of classification and the existing system of tests has changed the schools to a considerable extent into the "institutions for evaluation and classification of pupils" (various kinds of tests take roughly one third of the lessons and in view of the great amount of curriculum the teacher devotes a great part of the time left to the lecture and for a quality work with pupils and their creative approach to the individualization of teaching remains not enough time. ${ }^{4}$ Permanent tests cause an atmosphere of fear, and lead to higher nerve strain of students and teachers as well. Didn't now come time to evaluate the entire problem under a new angle of vision? Shouldn't we search also another forms of the feedback and use for it another criteria? The science nor the practice do not express to it in a sufficient extent for the time being.

What criteria should evaluate the level of the pedagogical work of the teacher and the school? The existing criteria do not correspond to the new conditions and other ones are so far not available A number of questions concerning the $o b$ jective school evaluation are at present really very relevant.

\footnotetext{
${ }^{4}$ J. Skalková, Obecná didaktika [General didactics], Praha 2017.
} 


\section{Education system and the problem of its control}

The schools now gradually acquire legal personality. What does it mean for the new designing of the control system? What will be the new role of the school institutions and the school council like?

The philosophy of the future school reform must necessarily count with a higher participation of municipalities and the public as representatives in the school councils, committees and likewise. The citizens so far do not know exactly what they should require and what are their competencies and the school institutions so far do not know how to communicate with them. The competencies can be created only on the basis of future cooperation.

The school reform is closely related to financing of the school system Financing of the schools becomes sometimes a problem on the part of municipalities (it is necessary to ensure the basic limit of financial means that the municipality is obliged to hand over to the school and not to leave the decision only on a good will of the municipality). The current question concerns the deliberation whether and how to subsidize the activity of the non-state schools (at schools with obligatory school attendance is likewise necessary to think about the fact whether the private, church and other schools should not receive the full subsidy per pupil as the state schools - see some experiences from abroad, for example from Denmark). Likewise it is incessantly necessary to consider the financial subsidies for the higher types of schools (full and shortened subsidy or without subsidy).

\section{Problem of the school reform itself}

Already the look at such a great complex of open questions outlined above (and its listing is far from being complete), shows that a question mark stands also over the reforms itself and the attempts for changes in the school system as well. Are we prepared for the reforms and changes in the school system? Have been carried out profound analyses of the insufficiencies in the school system and did we succeed in creation of the new philosophy of upbringing and education on its basis with reflection on the national traditions and world trends? We are afraid that not at all. Proposals that are presented by the small expert groups are in many aspects interesting but many of the questions outlined in this text as elementary ones have not been posed in these proposals, and remain unanswered.

\section{Conclusion}

Should we prepare reforms and changes in the school system under these conditions? Wouldn't its fate be the same as of many other reforms that have already affected our school system? Do we have any methodology of the school 
system reforms (system of preparations of materials, the relating discussion to it but also verification of the methodology in practice on smaller samples and other things? Is the area-wide reform of the school system justifiable as a concurrent one or should a differentiated approach take place? How are individual types of schools involved in transformation of the school system's development? Are we currently able to create a prognosis of our society's development in the forthcoming roughly twenty years, on which the considerations about the transformation of the school system could be based? We are afraid that not at all.

\section{BIBLIOGRAPHY}

Frankl V.E., Vưle ke smyslu [Volition to purpose], Cesta, Brno 1994.

Jedlička R., Kotáa J., Slavík J., Pedagogická psychologie pro učitele [Pedagogical psychology for the teachers], Grada Publishing, Praha: 2018.

Lorenz K., 8 smrtelných hř́chů [Eight mortal sins], Pyramida, Praha 1990.

Pelikán J., Výchova jako teoretický problém [Education as a theoretical problem], Amosium servis, Ostrava 1995.

Pelikán J., Pomáhat být: otevřené otázky teorie provázející výchovy [Help to be: open questions of the theory accompanying education], Karolinum, Praha 2002.

Semrád J., Vališová A., Andres P., Škrabal M., Výchova, vzdělávání a výzvy nové doby [Upbringing, education and challenges of the new times], Paido, Brno 2016.

Skalková J., Obecná didaktika [General didactics], Grada Publishing, Praha 2017 (5. dotisk).

Riesman D., Osamélý dav [Lonely crowd], Mladá fronta, Praha 1968.

Vališová A., Technical education of the youth - the priority of the Czech school system in the 21st century, Studia Edukacyjne, 2017, 46.

Vališová A., Kasíková H. a kol. Pedagogika pro učitele [Pedagogy for the teachers], Grada Publishing, Praha 2017 (5. dotisk).

Vališová A., Svoboda P., Vysokoškolský učitel v kontextu jeho profesní kompetence [Higher-education teacher in the context of his professional competency], Ostravská univerzita, Ostrava 2018. 